\title{
Farmers Status, Knowledge \& Management Practices on Major Chickpea Insect Pests in Some Selected Zones of Ethiopia
}

\author{
Tarekegn Fite ${ }^{1}$, Tadele Tefera ${ }^{1}$, Mulugeta Negeri ${ }^{2}$, Tebekew Damte ${ }^{3} \&$ Hirpa Legesse $^{4}$ \\ ${ }^{1}$ International Centre of Insect Physiology \& Ecology, Nairobi, Kenya \\ ${ }^{2}$ Department of Plant Sciences, Ambo University College of Agriculture \& Veterinary Science, Ambo, Ethiopia \\ ${ }^{3}$ Debre Zeit Agricultural Research Center, Ethiopian Institute of Agricultural Research, Debre Zeit, Ethiopia \\ ${ }^{4}$ Department of Plant Science, College of Agriculture and Natural Resource, Wallaga University, Nakamte, \\ Ethiopia \\ Correspondence: Tarekegn Fite, International Centre of Insect Physiology \& Ecology (ICIPE), Nairobi, Kenya. \\ Tel: 251-910-865-935. E-mail: tfduressa@gmail.com
}

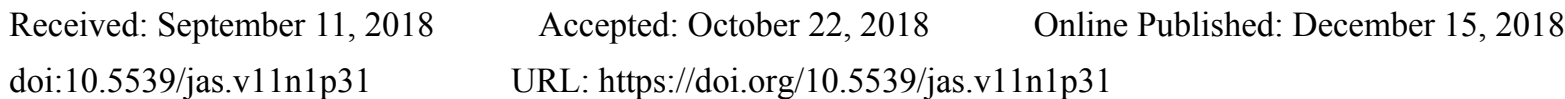

This research is financed by the USAID Feed the Future IPM Innovation Lab, Virginia Tech, Cooperative Agreement No. AID-OAA-L-15-00001.

\begin{abstract}
Survey were undertaken in five zones of Oromiya and Amhara regional states, Ethiopia from February to March 2018 to investigate farmers' status, knowledge, major chickpea production constraints and insect pest management practices of chickpea. The survey involved 293 randomly taken farmers, who are interviewed using a semi-structured questionnaire. Chickpea insect pests were considered as the main, among production constraints of chickpea by most of the interviewed farmers in Ethiopia. The majority of the farmers' responded that Helicoverpa armigera (Hübner) (Lepidoptera: Noctuidae) is the most prevalent insect pests of chickpea under field condition and Callosobruchus chinensis (L.) (Coleoptera: Bruchidae) in storage. Development Agents (DAs) were the top pest advisory service providers in the current study. A conventional insecticide (namely; Lambda-cyhalotrin and Dimethoate) for the control of $H$. armigera was the most commonly used pest management methods. Moreover, Two times insecticide applications per cropping season were the most frequent, deployed by most of the interviewed farmers followed by cultural pest management practices. Use of biological control and resistant chickpea varieties against major insect pests were low to negligible in the current survey study in the area. The majority of the farmers began control decision when $H$. armigera larval stages were smaller and they did not consider larval number per chickpea plant for the decision. These results will be used to formulate future effective and sustainable integrated pest management (IPM) in chickpea for Ethiopian farmers emphasizing ecologically and economically-based approaches.
\end{abstract}

Keywords: chickpea insect pests, Helicoverpa armigera, Integrated Pest Management (IPM), pest advisory service.

\section{Introduction}

Chickpea (Cicer arietinum L.) is the second most important pulse crop in terms of global production, after dry beans (Phaseolus vulgaris L.), with over 13.7 million metric tonnes produced annually (FAOSTAT, 2017). Ethiopia is the largest producer, consumer and exporter of chickpea in Africa and shares 4.5\% of global chickpea market and more than $60 \%$ of Africa's global chickpea market (Tebkew \& Ojiewo, 2016). The country is also considered as the secondary center of diversity for chickpea (Van der Maesen, 1987; Anbessa \& Bejiga, 2002). Chickpea is widely grown across the highlands and semi-arid regions of Ethiopia and serves as a multi/dual purpose crop. It plays major role in the daily diet of the rural community and parts of urban population, as source of income for farmers. Moreover, chickpea also generated foreign currency for the Ethiopian economy. Although chickpea is cultivated in most regions of the country; Amhara, Oromiya, Southern Nations, Nationalities and People's Region (SNNPR) and Tigray, in decreasing order, are the major producer regions. Amhara and Oromiya regions together produce 93 per cent of total chickpea production in Ethiopia, while SNNPR and Tigray produce 
3.5 and 3\%, respectively (Wasihun, 2016). The national average yields of chickpea in Ethiopia under farmers' production condition remains below the expected level in Ethiopia (Bejiga \& Daba, 2006; Menale et al., 2009; Keneni et al., 2011) and disproportionally, the potential of the crop under improved management condition is more than 3 tons per hectare (Dadi et al., 2005). However, production and productivity of chickpea is below the potential of chickpea due to adverse biotic and abiotic factors that in Ethiopia. Various factors limits the production and productivity of the crop such as biotic factors including insect pests cause major loss to the crop during on-farm, and storage and diseases, which necessitate development of integrated pest management packages. One of the major constraints upon establishing effective and sustainable IPM programme is the lack of adequate information about farmers' Knowledge, Perceptions and Practices (KPP) in pest management (Heong et al., 2002; Parsa et al., 2014). Farmers' perception based on local experience and indigenous knowledge, which provide valuable insights not presently covered in scientific literature, is important in pest management development (Debelo \& Degaga, 2015). Recognizing farmers' constraints and their existing technical knowledge is crucial to improve crop production and crop protection (Okolle et al., 2017; Rijal et al., 2018) and understanding on how research could be conducted to address the needs and constraints of farmers (Tefera, 2004; Sileshi et al., 2008; Ayuke, 2010).

Evaluating farmers' knowledge and perception of pests and natural enemies is especially useful to set research agendas, for planning campaign strategies and developing messages for communication (Midega et al., 2016; Okolle et al., 2017). Farmers' KPP in controlling field and storage maize pests has been well-documented (Debelo \& Degaga, 2015; Sileshi et al., 2008; Shuichi et al., 2011; Akutse et al., 2012; Asmare et al., 2014). Similar documentation is available for cotton (Arshad et al., 2009), coffee (Segura et al., 2004), maize (Midega et al., 2016), potatoes (Okonya \& Kroschel, 2016), mango (Akotsen-Mensah et al., 2017), vegetables (Nyirenda et al., 2011), olive (Allahyari et al., 2017), banana (Catherine et al., 2014), Fruit and Vegetables in Missouri (Pinero \& Keay, 2018), desmodium legumes in Kenya (Lefulesele et al., 2012) and maize in Ethiopia and Kenya (Kumela et al., 2018). Therefore, understanding farmers' indigenous knowledge, perceptions of insect pests and the decision making processes they follow in applying management practices could help to formulate sustainable pest management strategies relevant to local conditions and to identify the gap between research recommended and farmers' practices. However, there are no information on farmer's knowledge, production constraints and the practices used to management insect pests of chickpea under Ethiopian conditions. Moreover, updated and current information is crucial to map future insect pest management directions for resource poor chickpea farmers in Ethiopia. Thus, this study was conducted with the objective to assess farmers' status, knowledge, production constraints and management experiences on major insect pests of chickpea in some major chickpea production zones of Oromiya and Amhara regional sates, Ethiopia.

\section{Materials and Methods}

\subsection{Study Site}

The survey was conducted between February and March 2018 in five zones of Oromiya and Amara regional state, Ethiopia. These were West Showa $\left(09^{\circ} 01.303^{\prime} \mathrm{N}\right.$ to $\left.038^{\circ} 07.094^{\prime} \mathrm{E}\right)$, East Showa $\left(08^{\circ} 41.51^{\prime} \mathrm{N}\right.$ to $\left.039^{\circ} 03.545^{\prime} \mathrm{N}\right)$, North Showa $\left(08^{\circ} 54.703^{\prime} \mathrm{N}\right.$ to $\left.039^{\circ} 26.940^{\prime} \mathrm{E}\right)$, Southwest Showa $\left(08^{\circ} 50.788^{\prime} \mathrm{N}\right.$ to $\left.038^{\circ} 25.643^{\prime} \mathrm{E}\right)$, and Central Gonder zones $\left(12^{\circ} 26.829^{\prime} \mathrm{N}\right.$ to $\left.037^{\circ} 20.914^{\prime} \mathrm{E}\right)$ (Figure 1). These zones have large total chickpea production area and production in the country as we got production information from regional Bureau of Agriculture and Natural Resources. These zones were found with high to medium elevation (2285-1761 m above sea level) (Figure 1). 


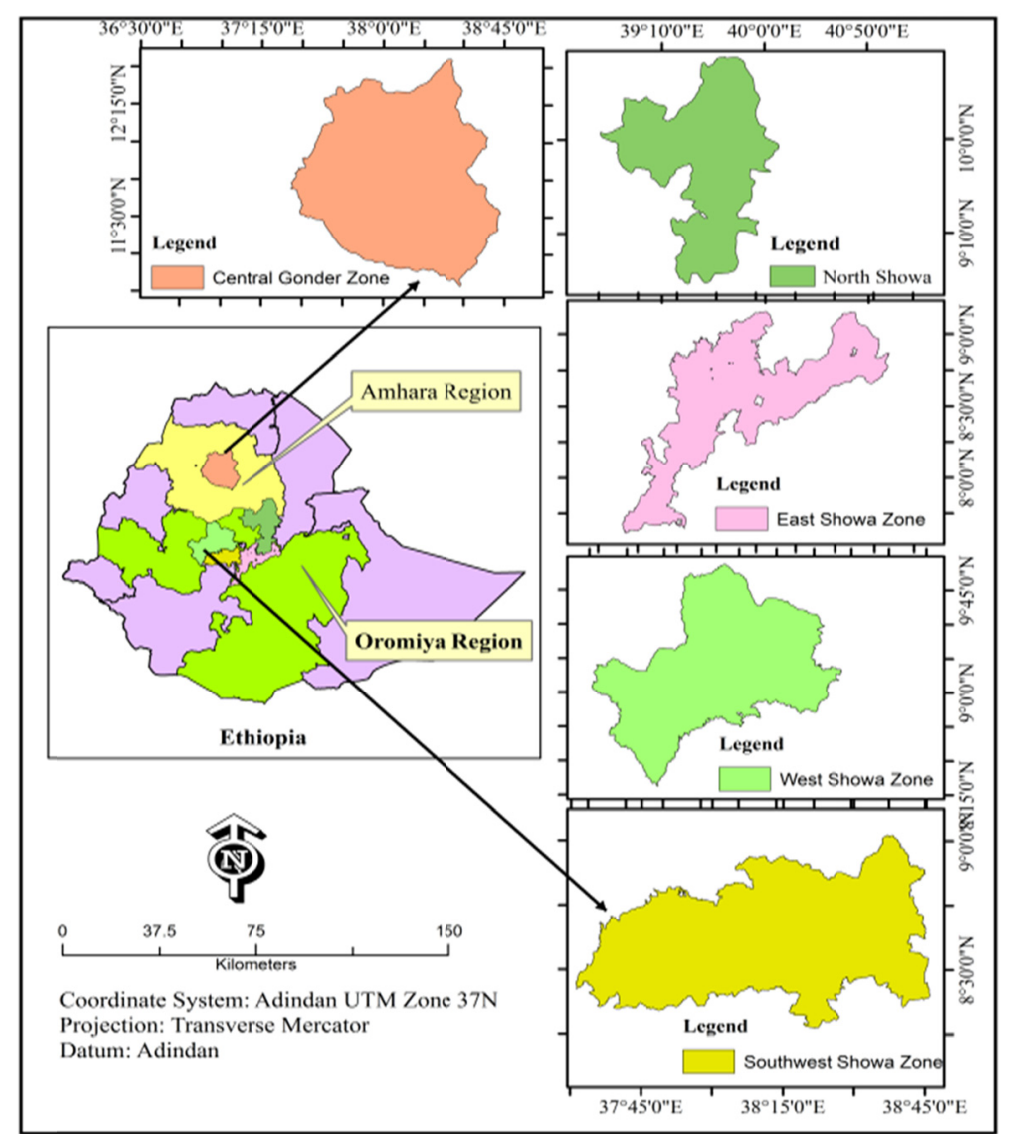

Figure 1. Map of Ethiopia showing Oromiya and Amhara regional states indication location of the study sites as indicated above

\subsection{Data Collection}

The survey data were collected using individual Semi-structured questionnaire which was prepared and pretested in Tokkee Kutayye $\left(08^{\circ} 59.316^{\prime} \mathrm{N}\right.$ to $037^{\circ} 47.398^{\prime} \mathrm{N}$, elevation 1956 above sea level) district on 10 randomly selected farmers prior to the actual survey. This pretest is to generate reliable and quality data, and clear picture of the farmers' knowledge, perceptions and management methods of chickpea insect pests that correct social research ethics were followed (Babbie, 2010).

Based up on the output of the pretest survey, the final questionnaire was ratified and administered by trained enumerators mainly Development Agents (DAs) to a total of 293 randomly selected farmers for about 30-50 minutes for each interviewee. Zones, Districts and Villages (Kebeles) were purposively selected based on the total chickpea area coverage and production using the information obtained from the respective bureau of agriculture. The interviews were conducted by translating the English to local language (Amharic and Afan Oromo). Chickpea producer farmers were randomly selected within the Villages.

Furthermore, household heads were the targeted respondents, although any adult/young who were familiar with chickpea production in the household were also considered for the interview when the heads of the household were absent. Including basic information on social economic status such as information access (mobile), age, gender, educational level, marital status and farming experience in agriculture and chickpea were collected for each individual. Data on sources of pest management advisory service, chickpea production constraints, major chickpea insect pests, rate and frequency of insecticide uses, and farmers' knowledge and perception of chickpea insect pests and management practices were collected through open-ended (categorical rank order scales) and closed questions (either 'yes' or 'no' questions).To assess farmers' perception on the type of the insect pests and severity of damage, photo of possible insect pests of chickpea in Ethiopia were printed in color and presented to farmers at the time of interview. Thereafter, farmers were asked to rate the importance of insect pests based on five scale points $(1=$ not important, $2=$ low, $3=$ medium, $4=$ high, and $5=\mathrm{I}$ do not know $)$. Larval size was classified to four classes $\left(1=\right.$ small larvae $\left(1^{\text {st }}\right.$ and $2^{\text {nd }}$ instar larvae $), 2=$ medium $\left(3^{\text {rd }}\right.$ and $4^{\text {th }}$ instar larvae $), 3=$ 
large $\left(5^{\text {th }}\right.$ and $6^{\text {th }}$ instar larvae $)$, and $0=$ no decision criteria) to assess whether or not farmers have decision criteria for applying insecticides.

\subsection{Data Analysis}

Closed responses, questions were coded prior to analysis. The survey data were analyzed through descriptive statistics (frequencies and percentage) to summarize and report responses to questions (Fink, 2009) and Pearson's Chi-squared analysis using SPSS Statistics (version 20) were used to determine association significance.

\section{Results}

\subsection{Socio-economic Characteristics of the Respondents}

Details of the demographic characteristics of respondents are indicated in Table 1. The majority of the respondents were male $(93.1 \%)$. Many $(56.52 \%)$ of the 293 farmers surveyed were in the middle age category (31-48 years), while $34.24 \%$ were above 49 years old, and $11.4 \%$ of , while only few of the respondents were younger (up to 30 years). In each zone more than $63 \%$ of the respondents had hand mobile phone for communication. With regard to education level of the respondents, most of the farmers have attended school (75.94\%) and $24.06 \%$ illiterate. Among the literate, 30 to $46 \%$ had undergone primary education, while few of the respondents had attended adult education (14\%), secondary school $(16.12 \%)$, tertiary $(0.44 \%)$ or Technical and Vocational Education and Training (TVET education) (2.65\%). The majority (24.5\%) of the interviewed farmers had 6-11 years of experience in chickpea production and an average of 11-30 years' experience in agriculture (60.16\%). 
Table 1. Summary of socio-economic characteristics, agricultural and chickpea farming experience of the interviewed farmers' in different zones of Ethiopia

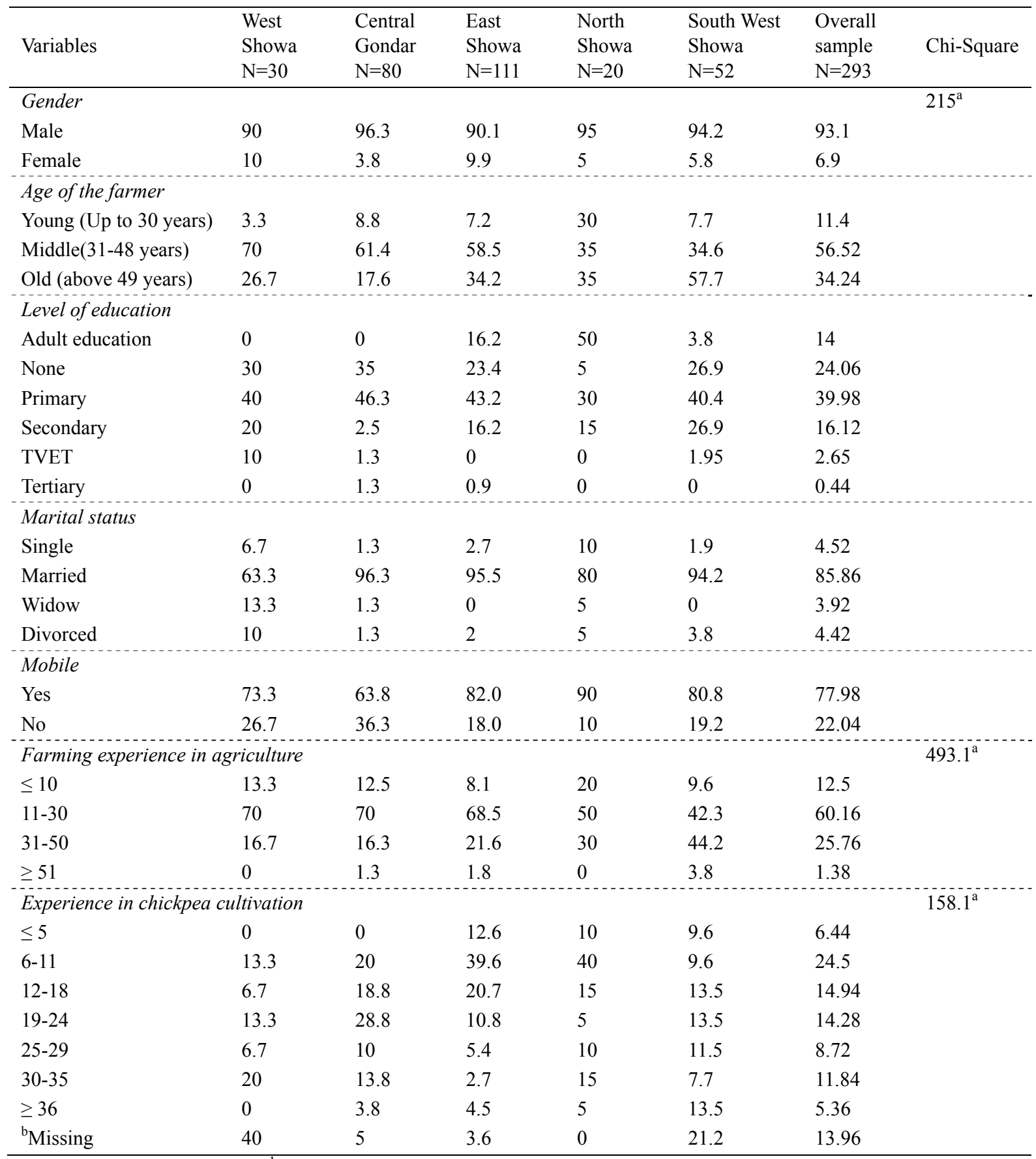

Note. ${ }^{a}$ significant at $1 \% .{ }^{\mathrm{b}}$ No respondents recognized date back of their experience years of chickpea production.

\subsection{Pest Advisory Services and Major Production Constraints}

The use of pest advisory services were common in the survey study area and the respondents got information from different sources (Table 2). Though the source of pest advisory services vary from zone to zone, the majority of the interviewed farmer was obtained the service of pest advisory (Figure 2). The majority of interviewed farmers obtained pest management advisory services from Agricultural Development Extension Agents (31.95\%) followed by neighbor (12.6\%), and relatives $(9.94 \%)$; while the contribution of other sources such as radio, field days, farmers group, television farmer's field school and Plant health clinic centers was negligible. On the other hand very few (4.2\%) respondents did not use information from any advisory services. 


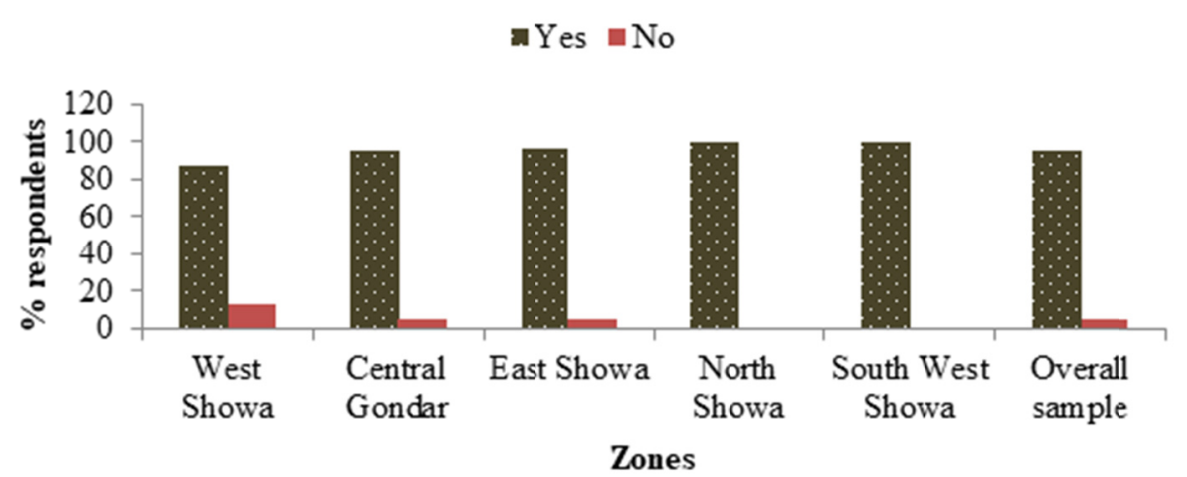

Figure 2. Pest advisor service in selected major chickpea producing zones of Oromiya and Amhara regions, Ethiopia

According to the respondents, four main constraints in chickpea production were diseases $(28.69 \%)$, insect pests (24.32\%), price $(12.31 \%)$ and climate change $(12.19 \%)$. Other production constraints that were considered as less important were drought, vertebrate pests, low yield of the crop, shortage of improved seed, excess rain fall, and lack of money (Table 2).

\subsection{Insect Pests of Chickpea and Insecticides Application Frequency and Rate}

All interviewed farmers in all zones knew field insect pest that attack their chickpea under field condition. Moreover, except in West and North Showa zones, storage insect pest on chickpea was reported in the remaining zones. The majority (54.96\%) of the respondents ranked African bollworm (Helicoverpa armigera (Lepidoptera: Noctuidae)) as number one insect pest, followed by cutworm (Agrotis ipsilon (Lepidoptera: Noctuidae)) (31.9\%), Aphids (16.2\%) and Bruchids (Callosobruchus chinensis (L.) (Coleoptera: Bruchidae)) (1.18\%) (Table 3). 
Table 2. Pest advisory sources and chickpea production constraints in the study area

\begin{tabular}{|c|c|c|c|c|c|c|c|}
\hline Variables & $\begin{array}{l}\text { West } \\
\text { Showa } \\
N=30\end{array}$ & $\begin{array}{l}\text { Central } \\
\text { Gondar } \\
\mathrm{N}=80\end{array}$ & $\begin{array}{l}\text { East } \\
\text { Showa } \\
N=111\end{array}$ & $\begin{array}{l}\text { North } \\
\text { Showa } \\
N=20\end{array}$ & $\begin{array}{l}\text { South West } \\
\text { Showa } \\
N=52\end{array}$ & $\begin{array}{l}\text { Overall } \\
\text { sample } \\
\mathrm{N}=293\end{array}$ & Chi-Square \\
\hline & \multicolumn{7}{|c|}{ 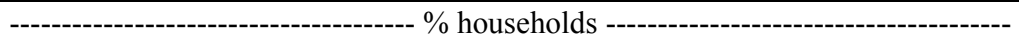 } \\
\hline Sources of pest advisory & & & & & & & $331.2^{\mathrm{a}}$ \\
\hline $\mathrm{DA}^{*}$ & 24.17 & 34.48 & 33.15 & 41.25 & 26.7 & 31.95 & \\
\hline Relatives & 5.33 & 6.71 & 8.94 & 25 & 3.46 & 9.94 & \\
\hline Neighbor & 23.37 & 13.64 & 10.2 & 0 & 5.76 & 12.6 & \\
\hline Field day** & 6.17 & 4.3 & 10.7 & 0 & 15.85 & 7.4 & \\
\hline Plant Health Clinic Center & 0 & 0.9 & 0.9 & 0 & 0 & 0.36 & \\
\hline Farmers field school & 4.67 & 6 & 0 & 0 & 6.28 & 3.39 & \\
\hline Television & 5.5 & 4.7 & 0 & 0 & 13.35 & 4.7 & \\
\hline Radio & 8.87 & 7.5 & 8 & 1.25 & 15.25 & 8.17 & \\
\hline Newspapers/leaflet & 0 & 0 & 0 & 0 & 0 & 0 & \\
\hline Farmers group & 2 & 6.6 & 9.54 & 5 & 6.28 & 5.89 & \\
\hline Not using & 13.3 & 5 & 2.7 & 0 & 0 & 4.2 & \\
\hline Missing & & & & & 3.8 & 0.76 & \\
\hline Chickpea production constraints & & & & & & & $546.56^{\mathrm{a}}$ \\
\hline Climate change & 11.94 & 10.2 & 11.85 & 9.1 & 17.86 & 12.19 & \\
\hline Vertebrates & 0 & 4.6 & 0 & 0 & 0.76 & 1.07 & \\
\hline Land shortage & 1.67 & 4.13 & 2 & 0 & 1.18 & 1.78 & \\
\hline Drought & 9.3 & 4.52 & 0.9 & 0 & 0.38 & 3.02 & \\
\hline Low yield & 8.64 & 6.14 & 3.3 & 1.66 & 2.56 & 4.46 & \\
\hline Labor shortage & 0 & 0 & 0 & 0 & 0 & 0 & \\
\hline Weeds & 1.1 & 2.63 & 9.3 & 1.66 & 8.29 & 4.59 & \\
\hline Insects & 22.1 & 30.5 & 23 & 24.16 & 21.88 & 24.32 & \\
\hline Diseases & 21.82 & 28 & 26 & 49.16 & 18.47 & 28.69 & \\
\hline Market & 12.56 & 7.13 & 16 & 9.1 & 16.76 & 12.31 & \\
\hline Shortage of improved chickpea seeds & 1.67 & 1.27 & 1.12 & 5 & 0.42 & 1.89 & \\
\hline Excess Rainfall & 0.66 & 2.2 & 4.5 & 0 & 0.76 & 1.62 & \\
\hline Availability of credit & 0.66 & 0.32 & 0 & 0 & 0.38 & 0.27 & \\
\hline
\end{tabular}

Note. ${ }^{\text {a }}$ Significant at $5 \%, * \mathrm{DA}=$ Development Agents, $* *$ Farmers Field day was organized by respective zones with collaborations of governmental and/or non-governmental organizations in the area.

A considerable proportion of respondents in Central Gondar, West Showa and Southwest Showa zones, in decreasing order, did not apply insecticide on chickpea, whereas larger proportion of respondents in North Showa and East Showa zones sprayed chickpea three or four times in a season. Moreover, about a third of the respondents in West Showa and Southwest Showa zones applied insecticide one time in a season. Respondents, who applied insecticides twice in a season, were greater in Central Gonder and east Showa zones than the remaining ones (Table 3 ). 
Table 3. Insect pests of chickpea, frequency and rate of insecticides applications per cropping season made by farmers against insect pests of chickpea in the study area

\begin{tabular}{|c|c|c|c|c|c|c|c|}
\hline Variables & $\begin{array}{l}\text { West } \\
\text { Showa } \\
\mathrm{N}=30\end{array}$ & $\begin{array}{l}\text { Central } \\
\text { Gondar } \\
\mathrm{N}=80\end{array}$ & $\begin{array}{l}\text { East } \\
\text { Showa } \\
\mathrm{N}=111\end{array}$ & $\begin{array}{l}\text { North } \\
\text { Showa } \\
N=20\end{array}$ & $\begin{array}{l}\text { South West } \\
\text { Showa } \\
\mathrm{N}=52\end{array}$ & $\begin{array}{l}\text { Overall } \\
\text { sample } \\
\mathrm{N}=293\end{array}$ & Chi-Square \\
\hline & \multicolumn{7}{|c|}{ 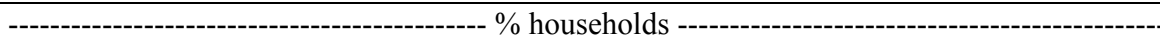 } \\
\hline Insect pests & & & & & & & $176.812^{\mathrm{a}}$ \\
\hline African bollworm & 61.6 & 48.2 & 65 & 55 & 45 & 54.96 & \\
\hline Aphids & 25 & 32.6 & 9.9 & 2.5 & 11 & 16.2 & \\
\hline Cutworm & 13.4 & 38.2 & 23 & 43 & 42 & 31.9 & \\
\hline Bruchids & 0 & 1.3 & 2.7 & 0 & 1.9 & 1.18 & \\
\hline \multicolumn{7}{|c|}{${ }^{b}$ Frequency of insecticides/cropping season } & $120.14^{\mathrm{a}}$ \\
\hline 1 time & 33.3 & 7.5 & 13.5 & 15 & 32.7 & 20.4 & \\
\hline 2 times & 20 & 31.3 & 33.3 & 10 & 21.2 & 23.16 & \\
\hline 3 times & 10 & 12.5 & 24.3 & 30 & 21.2 & 19.6 & \\
\hline$\geq 4$ times & 3.3 & 1.3 & 26.1 & 45 & 1.9 & 15.52 & \\
\hline c Not apply & 33.3 & 47.5 & 2.7 & 0 & 23.1 & 21.32 & \\
\hline \multicolumn{7}{|l|}{ Application rate/ha } & $344.45^{\mathrm{a}}$ \\
\hline $1 \mathrm{~L}$ & 43.3 & 31.3 & 71.2 & 35 & 67.3 & 49.62 & \\
\hline $2 \mathrm{~L}$ & 20 & 12.5 & 9 & 45 & 5.8 & 18.42 & \\
\hline $3 \mathrm{~L}$ & 3.3 & 1.3 & 1.8 & 15 & 5.8 & 5.44 & \\
\hline$\geq 4 \mathrm{~L}$ & 0 & 6.3 & 14.4 & 5 & 5.8 & 6.3 & \\
\hline${ }^{\mathbf{c}}$ Not apply & 33.3 & 47.5 & 1.8 & 0 & 21.2 & 20.76 & \\
\hline As recommended & 0 & 1.3 & 1.8 & 0 & 0 & 0.62 & \\
\hline
\end{tabular}

Note. ${ }^{\mathrm{a}}$ Significant at $1 \%{ }^{\mathrm{b}}$ Insecticides applications against $H$. armigera under field condition; ${ }^{\mathrm{c}}$ The respondents do not spray any insecticides due to economic concern (They relate the effectiveness of synthetic insecticides against $H$. armigera and cost, and prices of chickpea return).

Among those respondents who apply insecticides (mostly they use Karate 5 EC (Lambda-cyhalotrin) and Dimeto $40 \%$ EC (Dimethoate)) on chickpea, larger (49.62\%) proportion of them applied insecticide at the rate of one liter per hectare, while fewer respondents applied two $(18.42 \%)$ or more liters per hectare (three litre $(5.44 \%), \%)$, and $\geq 4$ litre $(6.3 \%)$ per hectare). In all zones, the proportion of respondents who applied at the recommended rate was negligible $(0.62 \%)$ (Table 3$)$. About $20.76 \%$ of the respondents were those who didn't use insecticide. Insecticide application rate showed a high variation among zones of the study areas (Table 1).

\subsection{Decision Criteria for Applying Insecticides}

In all zones, the majority farmers who sprayed insecticide on chickpea used larva size as decision criterion for spraying insecticides. Thus, 59, 32, and 5\% of the respondent's used small, medium and large larva size, respectively, as decision criterion, whereas only $4 \%$ of them have no decision criterion for insecticide application (Figure 3A). 


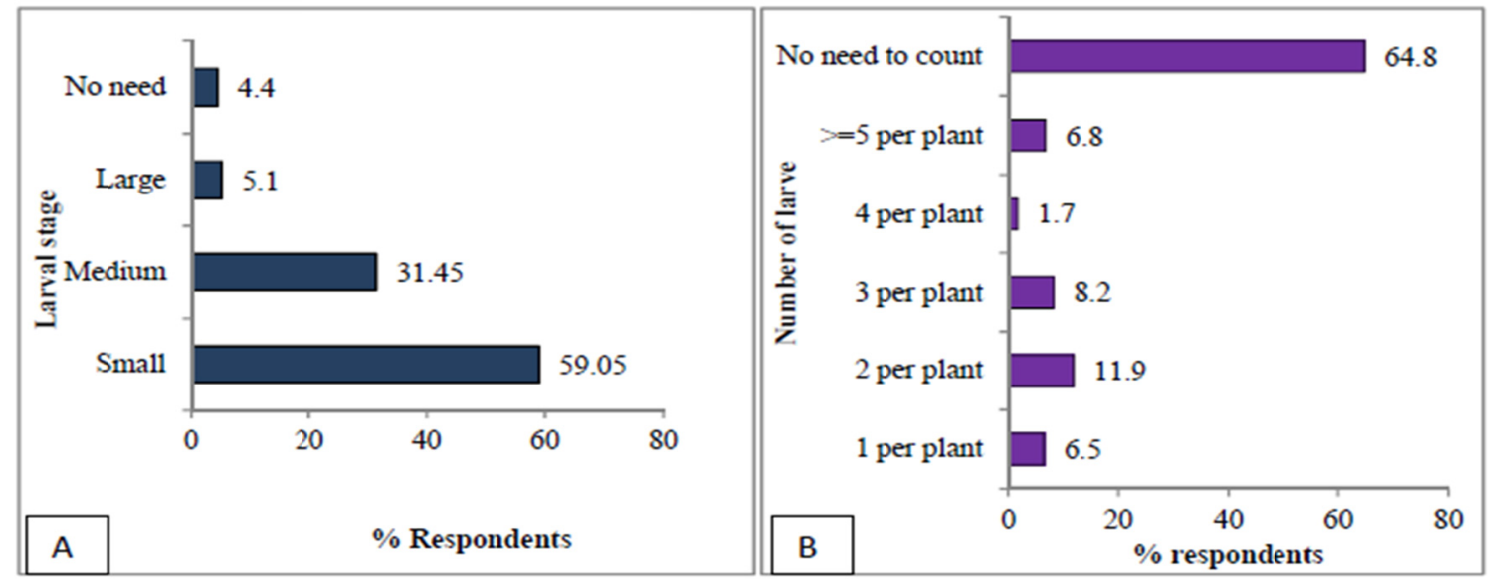

Figure 3. A) Decision criteria for insecticides applications used by farmers to manage H. armigera in chickpea; B) The proportion of farmers who used larvae number as decision criterion for insecticides applications against H. armigera in chickpea

Figure 3B shows the proportion of farmers who decide to spray insecticide based on larvae number per plant. The majority of the respondents $(64.8 \%)$ indicated that they did not use larvae number as criterion for insecticide application, while only $7,12,8,2$, and $7 \%$ of the respondents decided to spray when larvae number per plant are one, two, three, four, and $\geq 5$, respectively.

\subsection{Insect Pest Management Methods Employed by Chickpea Farmers}

The types of pest management methods practiced by the respondents (farmers) are indicated in Table 4. Except in central Gondar zone where cultural control method was dominant, conventional insecticides control was the most commonly used pest management method with percentages values varying from $40.4 \%$ in South West Showa to $80 \%$ in North Showa (Table 4).

Table 4. Farmer's responses on management practices used for chickpea insect pest attacks in different zones of Ethiopia

\begin{tabular}{|c|c|c|c|c|c|c|c|}
\hline Variables & $\begin{array}{l}\text { West } \\
\text { Showa } \\
N=30\end{array}$ & $\begin{array}{l}\text { Central } \\
\text { Gondar } \\
\mathrm{N}=80\end{array}$ & $\begin{array}{l}\text { East } \\
\text { Showa } \\
N=111\end{array}$ & $\begin{array}{l}\text { North } \\
\text { Showa } \\
\mathrm{N}=20\end{array}$ & $\begin{array}{l}\text { South West } \\
\text { Showa } \\
\mathrm{N}=52\end{array}$ & $\begin{array}{l}\text { Overall } \\
\text { sample } \\
\mathrm{N}=293\end{array}$ & Chi-Square \\
\hline & \multicolumn{7}{|c|}{$\%$ households } \\
\hline${ }^{\mathrm{b}}$ Insecticides & 66.7 & 40.4 & 61.3 & 80 & 40.4 & 57.7 & $472.461^{\mathrm{a}}$ \\
\hline${ }^{\mathrm{c}}$ Cultural practices & 33.4 & 50.4 & 30.6 & 20 & 19.8 & 30.8 & \\
\hline${ }^{\mathrm{d}}$ Biological control & 0 & 5.43 & 3.6 & 0 & 30.1 & 7.8 & \\
\hline${ }^{\mathrm{e}}$ Resistant/tolerant chickpea varieties & 0 & 2.5 & 4.5 & 0 & 9.6 & 3.32 & \\
\hline
\end{tabular}

Note. ${ }^{a}$ significant at $1 \% .{ }^{\mathrm{b}}$ Karate 5 EC (Lambda-cyhalotrin) and Dimeto $40 \%$ EC (Dimethoate) are the most commonly used insecticides against $H$. armigera in chickpea by farmers in the study area ${ }^{\mathrm{c}}$ Larger larval hand picking was also practiced by most farmers, afterward they fed chicken. ${ }^{\mathrm{d}}$ Commonly, the respondents allow larger and smaller birds to collect the larvae from the chickpea fields. ${ }^{e}$ Respondents use local landrace chickpea varieties, mainly they believe that Desi type chickpea varieties as moderate resistant to pod borer $(\mathrm{H}$. armigera $)$ than Kabuli types.

The most commonly used insecticides were Lambda-cyhalotrin and Dimethoate for the control of $H$. armigera. Cultural control (30.8\%) was the second major method practiced by farmers in all zones except southwest Showa zone, where the use of biological control (7.8\%) is the second most important method of pod borer control. The use of host plant resistance as control method is negligible in all zones (Table 4).

\section{Discussion}

The current survey result has demonstrated that chickpea insect pest knowledge; pest advisory services and management practices employed by farmers' are variable across the studied zones. There were more male headed 
households than women headed households as larger proportions of the respondents were married. The information generated in the current survey study was likely to be biased by gender in all study area because chickpea production was dominated by male in all zones; this is probably because chickpea is more of a commercial than food security crop. It has been reported that in many African countries, men dominated cash crop production (World Bank, 2009).

Our study showed that chickpea are grown mostly by younger aged farmers (active age). This suggests that chickpea as important grain legumes; have great potential to alleviate poverty and contribute to farmers income as cash crop (CGIAR, 2012) and attractive to empower the younger generation in Ethiopia. According to Adenegan et al. (2013), age significantly influences farm and farmer productivity. Farmers education levels have great implication for farmers' efficiency in agricultural production and productivity, to adopt new technologies, proper pesticide application and decision-making (Gaber \& Abdel-Latif, 2012; Abang et al., 2014). Except in North Showa zone, where there were few illiterate respondents, on the average more than a quarter of the respondents in the remaining zones were illiterate.

Most of the interviewed farmers were mobile phone users so that farmers share new information among themselves and as interpersonal communication; as means of information transfer technology in the study area. Padel (2001) found that new communication technologies such as mobile phone can increase farmers' participation toward IPM diffusion and emphasizing to using new communication devises which can be useful toward IPM adoption. In Australia, growers and agronomists are very amenable to the use of ICT as a method to provide immediate and up-to-date information in relation to pest and diseases in crops (Wright et al., 2018). Despite the majority of farmers were 11-30 years of agricultural farming experiences, most of them had 6-11 years of experience in chickpea production, suggesting that chickpea production in Ethiopia was seems to be a recent development in some area.

In the current survey study, we found that most farmers are aware of the major production constraints in general and insect pests of chickpea in particular. Chickpea insect pests and diseases are the two most important constraints of chickpea production throughout chickpea growing regions of the world. Various authors asserted that insect's pests, mainly H. armigera (Baskar et al., 2011; Fernandes et al., 2015; Tebkew \& Ojiewo, 2017) and diseases particularly wilt and root rot (WRR) complex diseases (Luciana et al., 2016, Tebkew \& Ojiewo 2016; Mathew et al., 2018) are major chickpea production constraints in Ethiopia and elsewhere. The high mean percent wilt and root rot incidence and percent severity index in Gojam followed by Gondar and the lowest in Showa, Ethiopia by Yimer et al. (2018), who revealed high prevalence of chickpea diseases in Ethiopia and causing economic yield loss was an evident for our survey result study.

In each zone, nearly equal proportion of respondents identified diseases and insect pests as major constraints of chickpea production, whereas only few of them considered weeds as problem. Farmers identified African bollworm ( $H$. armigera) as the most prevalent insect pest of chickpea in Ethiopia, even before larval and pod damage pictures were shown to them, which suggests that farmers have good knowledge of H. armigera. Previous studies in Ethiopia have also shown that $H$. armigera as the most prevalent insect pests of chickpea (Tebkew \& Ojiewo, 2017) and elsewhere in major chickpea production regions of the world (Blum et al., 2018; Mahid et al., 2008). Some farmers also reported that cutworm (A. ipsilon), is economically important pest of chickpea in some location in some years, which is due to it's sporadic nature and considered as minor insect pest of chickpea (Abraham \& Firdissa, 2008). Furthermore, C. chinensis was also considered as the most common insect pest that attack chickpea seed in storage (Kenei et al., 2011; Adugna, 2015).

Developmental agents (DAs) were the main sources of pest management advisory service providers in the study areas; indicating that farmers are aware on the use of pest management practices in their chickpea farms, even though pest management options are limited. For instance, the majority of the farmers were able to decide for insecticide application when larval stages were at early (smaller) this mean farmers were aware on when to apply insecticides. The present survey is agreement with Mohammadrezaei \& Hayati (2015); Lukuyu et al. (2012); Benjamin (2013); Baloch \& Thapa (2016) and Emmanuel et al. (2016) who believed that agricultural extension services are the main diffusion technology instruments which impacts on farmers' knowledge and skills as well as on production. Daniel et al. (2011) reported that training in pest epidemiology and crop management improved farmers' knowledge and led to better understanding of the pest epidemiology, so that the incidence of pests declined and cocoa yields increased by an average of 30\%. Various authors working in Kenya and Nigeria have found a significant positive relationship between farmers' knowledge of insect pests and socioeconomic factors such as household size, gender, farming experience, and education (Midega et al., 2016; Zhang et al., 2018). 
Most of the farmers mentioned chemical insecticides as the main methods used for controlling field insect pests of chickpea. Such dependency on synthetic insecticides had arisen because most farmers believe that pesticides are reliable control method for chickpea insect pests. However, lack of awareness on and/or unavailability of other control measures are the likely reason for the sole reliance by farmers on synthetic insecticides. Similar results have been reported in many developing countries where growing dependence on synthetic insecticides/non-IPM for the control of crop pests is alarming (Khan et al., 2015; Kumela et al., 2018; Zhang et al., 2018, Ochilo et al., 2018; Bonaventure et al., 2018). Farmer's reliance on intensive pesticide application was also common for other crops such as cotton, mango, maize, tomato, eggplants, and cabbages and other vegetables in various countries (Munyuli, 2016; Akotsen-Mensah et al., 2017, Rumbidzai et al., 2017; Kumela et al., 2018). However, the intensive and irrational use of non-selective insecticides for pest control was resulted in pest resurgence, development of insecticide resistant strains, environmental pollution, ecological imbalance and elimination of natural enemies (Thanavendan \& Jeyarani, 2010; Tiwari et al., 2011). Mostly they used two times per cropping season at the rate of 1 litre per hectare. In relative to previous report, application frequencies of insecticides were low in the current finding, which suggests that most of the interviewed farmers was received pest advisory services from various source providers. Even though the majority of the interviewed farmers were using insecticides against $H$. armigera, they indicated that the insecticides are not effectives perhaps due to the larval feeding habits (the larvae fed inside the pods) most do no use the recommended rate as labelled and perhaps, resistance development to most of the conventional insecticides. Therefore, farmers are not getting an acceptable result, but increased cost of production of chickpea.

Chickpea producers in the study area did not use economic threshold level in making decisions to spray insecticides. Instead the majority of the interviewed farmers base their decision on the larval stage of $H$. armigera. This is because economic threshold level for the majority of economically important insect pests has not been established under Ethiopian condition. It has been well documented that pest identification and recognition is crucial for a successful pest management program (Damalas \& Koutroubas, 2014; Abtew et al., 2016; Midega et al., 2016). Khan and Damalas (2015) reported that small farm holders have difficulties in pest recognition and the understanding of pest ecology. In order to achieve better control, identification and recognizing of insect pest stage was crucial in sustaining effective pest control and determinant of farmer's knowledge. Chen et al. (2013) and Khan et al. (2015) reported that lack farmer's knowledge of pest management and control is one of the factors affecting farmers' pesticide use in practice.

\section{Conclusion}

In conclusion, this survey study provides some vital information to better understand of farmers status, pest advisory service, major chickpea production constraints, pest knowledge and the management practices employed in chickpea production in the area. Chickpea was considered as cash crop by most farmers hence, dominated by men household. Chickpea diseases and insect pests were considered as the most production constraints of chickpea by most of the interviewed farmers. The majority of the farmers' were responded $H$. armigera as the most prevalent insect pests of chickpea under field condition and bruchid in storage. Development agents were the main pest advisory service provider, which should be strengthened especially focusing on the issues of crop protection. Although, plant health clinic centers were full mandated with plant health/crop protection, their role in providing technical training for farmers were negligible in the present survey study areas. A conventional insecticide for the control of $H$. armigera was the most commonly used a pest management method which is an indication of reliance on synthetic insecticides. Two times frequent applications per cropping season. Additionally, farmers also deployed cultural pest management practices in some area. The use of biological control and resistant chickpea varieties against major insect pests were not common by most farmers. Farmers began control decision when $H$. armigera larval stage was smaller and they did not consider larval number for the decision hence, economic threshold level for the majority of economically important insect pests has not been established under Ethiopian condition however, requires further studies. Any future pest management should consider farmers status, knowledge and the pest management practices employed under their condition so that, the new information generated would be used as an input to formulate future effective and sustainable integrated pest management (IPM) in chickpea emphasizing on social acceptability, ecological consideration and economically-based approaches.

\section{Acknowledgements}

This study was supported by the USAID Feed the Future IPM Innovation Lab, Virginia Tech, Cooperative Agreement No. AID-OAA-L-15-00001. Tarekegn Fite is an icipe student supported by the USAID Feed the Future IPM Innovation Lab, Virginia Tech, under the provision of Rice, Maize, \& Chickpea IPM Project for East Africa. We also gratefully acknowledge the financial support by the UK's Department for International 
Development (DFID); Swedish International Development Cooperation Agency (Sida); the Swiss Agency for Development \& Cooperation (SDC); and the Kenyan Government. The views expressed herein do not necessarily reflect the official opinion of the donors. Moreover, our thankful acknowledgment also goes to all icipe staff.

\section{References}

Abang, A. F., Kama, C. M., Abang, M., Hanna, R., \& Fotso, A. K. (2014). Assessing vegetable farmer knowledge of diseases and insect pests of vegetable and management practices under tropical conditions. International Journal of Vegetable Science, 20, 240-253. https://doi.org/10.1080/19315260.2013.800625

Abraham, T., \& Firdissa, E. (2008). Insect pests of farm stored maize and their management practices in Ethiopia. Integrated Protection of stored Products. IOBC Bulletin, 23(10), 47-57.

Abtew, A., Niassy, S., Affognon, H., Subramanian, S., Kreiter, S., Garzia, G. T., \& Martin, T. (2016). Farmers' knowledge and perception of grain legume pests and their management in the Eastern province of Kenya. Crop Protection, 87, 90-97. https://doi.org/10.1016/j.cropro.2016.04.024

Adenegan, K. O., Adams, O., \& Nwauwa, L. O. E. (2013). Gender impacts of small-scale farm households on agricultural commercialisation in Oyo State, Nigeria. Br. J. Econ. Manage. Trade, 3, 1-11. https://doi.org/ 10.9734/BJEMT/2013/1910

Adugna, H. (2015). Eco-friendly management of chickpea storage pest, Callosobruchus chinensis L. (Coleoptera: Bruchidae) under laboratory conditions in Eritrea. J. of Stored Products and Postharvest Research, 6(8), 66-71. https://doi.org/10.5897/JSPPR2015.0175

Akotsen-Mensah, C., Ativor, I. N., Anderson, R. S., Afreh-Nuamah, K., Brentu, C. F., Osei-Safo, D., ... Avah, V. (2017). Pest management knowledge and practices of mango farmers in Southeastern Ghana. Journal of Integrated Pest Management, 8(1), 1-7. https://doi.org/10.1093/jipm/pmx008

Akutse, K. S., Owusu, E. O., \& Afreh-Nuamah, K. (2012). Perception of farmers' management strategies for termites control in Ghana. Journal of Applied Bioscience, 49, 3394-3405.

Allahyari, M. S., Damalas, C. A., \& Ebadattalab, M. (2017). Farmers' technical knowledge about integrated pest management (IPM) in olive production. Agriculture, 7, 101. https://doi.org/10.3390/agriculture 7120101

Anbessa, Y., \& Bejiga, G. (2002). Evaluation of Ethiopian chickpea landraces for tolerance to drought. Genetic Resources and Crop Evolution, 49, 557-64. https://doi.org/10.1023/A:1021210601480

Arshad, M., Suhail, A., Dildar, M., Gogi, M., Yaseen, M., Asghar, M., ... Unsar, N. U. (2009). Farmers' perceptions of insect pests and pest management practices in $B t$ cotton in the Punjab, Pakistan. International Journal of Pest Management, 55(1), 1-10. https://doi.org/10.1080/0967087080 2419628

Asmare, D., Emana, G., Amare, A., \& Ferdu, A. (2014). Distribution and impact of Busseola fusca (Fuller) (Lepidoptera: Noctuidae) and Chilo partellus (Swinhoe) (Lepidoptera: Crambidae) in Northeastern Ethiopia. Journal of Entomology and Nematology, 6(1), 1-13. https://doi.org/10.5897/JEN2013.0078

Ayuke, F. O. (2010). Soil macrofauna functional groups and their effects on soil structure, as related to agricultural management practices across agroecological zones of Sub-Saharan Africa (p. 211, Ph.D. Thesis, Wageningen University, Wageningen).

Babbie, E. (2010). The Practice of Social Research. Wadsworth, Cengage Learning, Belmont.

Baloch, M. A., \& Thapa, G. B. (2016). The effect of agricultural extension services: Date farmers' case in Balochistan, Pakistan. Journal of the Saudi Society of Agricultural Sciences.

Baskar, K., Sasikumar, S., Muthu, C., Kingsley, S., \& Ignacimuthu, S. (2011). Bioefficacy of Aristolochia tagala cham. against Spodoptera litura fab. (Lepidoptera: noctuidae). Saudi. Journal of Biological Science, 18(1), 23-27. https://doi.org/10.1016/j.sjbs.2010.09.004

Bejiga, G., \& Daba, K. (2006). Breeding chickpea for wide adaptation. In Kemal et al. (Eds.), Food and forage legumes of Ethiopia progress and prospects (pp. 59-66). ICARDA, Addis Ababa, Ethiopia.

Bejiga, G., Eshete, M., \& Anbessa, Y. (1996). Improved Cultivars and Production Technology of Chickpea in Ethiopia (p. 60, Research Bulletin No. 2). Debre Zeit Agricultural Research Center, Debre Zeit. 
Benjamin, A. M. N. (2013). Farmers' perception of effectiveness of agricultural extension delivery in cross-river state Nigeria. IOSR Journal of Agriculture \& Veterinary Science, 2(6), 01-07. https://doi.org/10.9790/23800260107

Blum, M., Nestelb, D., Cohenc, Y., Goldshteinc, E., Helmana, D., \& Lenskya, I. M. (2018). Predicting Heliothis (Helicoverpa armigera) pest population dynamics with an age-structured insect population model driven by satellite data. Ecological Modelling, 369, 1-12. https://doi.org/10.1016/j.ecolmodel.2017.12.019

Bonaventure, J., Gration, M. R., \& Tefera, T. (2018). Farmers' Perceptions of Rice Production Constraints and Stem Borers Management Practices in Tanzania. Journal of Agricultural Science, 10(6), 1916-9760. https://doi.org/10.5539/jas.v10n6p57

Catherine, H. A., Lasalita-Zapico, F., Namocatcat, J., Fortich, A., \& Bojadores, R. M. (2014). Farmers' perceptions about banana insect pests and integrated pest management (IPM) systems in SocSarGen, Mindanao, Philippines. International Conference on Intelligent Agriculture IPCBEE, IACSIT Press, Singapore.

CGIAR. (2012). Grain Legumes, Leveraging Legumes to Combat Poverty, Hunger, Malnutrition and Environmental Degradation. Consultative Group on International Agricultural Research. Retrieved from https://cgspace.cgiar.org/handle/10947/5316

Chen, R., Huang, J., \& Qiao, F. (2013). Farmers' knowledge on pest management and pesticide use in Bt cotton production in china. China Economic Review, 27, 15-24. https://doi.org/10.1016/j.chieco.2013.07.004

Dadi, L., Regasssa, S., Fikre, A., \& Mitiku, D. (2005). Adoption of chickpea varieties in the central highlands of Ethiopia (Research Report 62). EARO (Ethiopian Agricultural Research Organization), Addis Ababa, Ethiopia.

Damalas, C. A., \& Koutroubas, S. D. (2014). Determinants of farmers' decisions on pesticide use in oriental tobacco: A survey of common practices. International Journal of Pest Management, 60(3), 224-231. https://doi.org/10.1080/09670874.2014.958767

Daniel, G., \& Emana, G. (2015). Farmers' knowledge, perceptions and management practices of termites in the central rift valley of Ethiopia. African Journal Agricultural Research, 10(36), 3625-3635. https://doi.org/ $10.1080 / 09670874.2014 .958767$

Daniel, R., Konam, J. K., Saul-Maora, J. Y., Kamuso, A., Namaliu, Y., Vano, J. T., ... Guest, D. I. (2011). Knowledge through participation: the triumphs and challenges of transferring Integrated Pest and Disease Management (IPDM) technology to cocoa farmers in Papua New Guinea. Food Secur., 3, 65-79. https://doi.org/10.1007/s12571-011-0115-6

Debelo, D. G., \& Degaga, E. G. (2015). Farmers Knowledge, perception and management practices of termite in the central rift valley of Ethiopia. African Journal Agricultural Research, 10(36), 3625-3635. https://doi.org/10.5897/AJAR2014.9283

Emmanuel, D., Owusu-Sekyere, E., Owusuc, V., \& Jordaan, H. (2016). Impact of agricultural extension service on adoption of chemical fertilizer: Implications for rice productivity and development in Ghana. NJAS-Wageningen. Journal of Life Sciences, 79, 41-49. https://doi.org/10.1016/j.njas.2016.10.002

FAOSTAT (Food \& Agriculture Organization). (2017). Retrieved from http://www.fao.org/faostat/en/\#data/QC

Fernandes, A. P., Bueno, A. F., \& Sosa-Gómez, D. R. (2015). Helicoverpa armigera: Current status and future perspectives in Brazil. Current Agricultural Science \&Technology, 21(1), 1-7.

Fink, A. (2009). How to Conduct Surveys: A Step-by-step Guide. Sage Publications, Inc., Thousand Oaks.

Gaber, S., \& Abdel-Latif, S. H. (2012). Effect of education and health locus of control on safe use of pesticides: a cross sectional random study. J. Occup. Med. Toxicol, 7. https://doi.org/10.1186/1745-6673-7-3

Geletu, B., Million, E., \& Yadeta, A. (1996). Improved cultivars and production Technology of chickpea in Ethiopia (p. 60, Research Bulletin No. 2). Debre zeit Agricultural research Center, Debre Zeit, Ethiopia.

Heong, K. L., Escalada, M. M., Sengsoulivong, V., \& Schiller, J. (2002). Insect management beliefs and practices of rice farmers in Laos. Agriculture, Ecosystems \& Environment, 92(2-3), 137-145. https://doi.org/ 10.1016/S0167-8809(01)00304-8

Kemal, A., \& Tibebu, H. (1994). Research on insect pests of cool-season food legumes. In A. Tilaye, G. Bejiga, M. C. Saxena, \& M. B. Solh (Eds.), Coolseason Food Legumes of Ethiopia (pp. 367-396). Proceeding of 
the First National Cool-Season Food Legumes Review Conference, 16-20 December 1993, Addis Ababa, Ethiopia. ICARDA/IAR, Syria.

Keneni, G., Bekele, E., Imtiaz, M., Getu, E., Dagne, K., \& Assefa, F. (2011). Breeding chickpea (Cicer arietinum) for better seed quality inadvertently increased susceptibility to adzuki bean beetle (Callosobruchus chinensis). International Journal of Tropical Insect Science, 31(94), 249-261. https://doi.org/10.1017/S17 42758411000373

Khan, M., \& Damalas, C. A. (2015). Farmers' knowledge about common pests and pesticide safety in conventional cotton production in Pakistan. Crop Protection, 77, 45-51. https://doi.org/10.1016/j.cropro. 2015.07.014

Kumela, T., Josephine, S., Birhanu, S., Paddy, L., Esayas, M., Linnet, G., \& Tefera, T. (2018). Farmers' knowledge, perceptions, and management practices of the new invasive pest, fall armyworm (Spodoptera frugiperda) in Ethiopia and Kenya. International Journal of Pest Management. https://oi.org/10.1080/ 09670874.2017.1423129

Lefulesele, N., Lebesa, Z., Khan, R., Kerstin, K., Toby, J., Bruce, A., Ahmed, H., \& John, A. (2012). Farmers' knowledge and perceptions of blister beetles, Hycleus spp. (Coleoptera: Meloidae), as pest herbivores of Desmodium legumes in western Kenya. International Journal of Pest Management, 58(2), 165-174. https://doi.org/10.1080/09670874.2012.673032

Luciana, B., Castelli, M. V., Barolo, M. I., \& Mostacero, R. N., Tosello, M. E., \& López, S. N. (2017). Ascochyta blight: isolation, characterization, and development of a rapid method to detect inhibitors of the chickpea fungal pathogen Ascochyta rabiei. Fungal Biology, 120(3), 424-432.

Lukuyu, B., Place, F., Franzel, S., \& Kiptot, E. (2012). Disseminating improved practices: Are volunteer farmer trainers effective? Journal of Agricultural Education \& Extension, 18(5), 525-540. https://doi.org/10.1080/ 1389224X.2012.707066

Mathew, S., Sunil, B., \& Dubey, C. (2018). Pathogenic variability of Ascochyta rabiei causing blight of chickpea in India. Physiological \& Molecular Plant Pathology, 102, 122-127. https://doi.org/10.1016/j.pmpp.2018. 01.001

Menale, K., Shiferaw, B., Asfaw, S., Abate, T., Muricho, G., Ferede, S., ... Assefa, K. (2009). Current situation and future outlooks of the chickpea sub-sector in Ethiopia. EIAR (Ethiopian Institute of Agricultural Research) and ICRISAT (International Crops Research Institute for the Semi-Arid).

Midega, C. A. O., Murage, A. W., Pittchar, J. O., \& Khan, Z. R. (2016). Managing storage pests of maize: Farmers' knowledge, perceptions and practices in western Kenya. Crop Protection, 90, 142-149. https://doi.org/10.1016/j.cropro.2016.08.033

Mohammadrezaei, M., \& Hayati, D. (2015). The role of agricultural extension services in integrated pest management adoption by Iranian pistachio growers. International Journal of Agricultural Extension, 3(01), 45-56.

Munyuli, T. M. B. (2016). Assessment of the current status of pesticide use, trade and regulation and outline of action plans for safer application of pesticides in DR Congo. A draft consultancy report submitted to the Cadmus Group/GEMS under the PERSUAP-USAID/RD Congo mission-wide agricultural activities in North-Kivu and South-Kivu Provinces.

Nyirenda, S. P., Sileshi, G. W., Belmain, S. R., Kamanula, J. F., Mvumi, B. M., Sola, P., ... Stevenson, P. C. (2011). Farmers' ethno-ecological knowledge of vegetable pests and their management using pesticidal plants in Northern Malawi and Eastern Zambia. African Journal of Agricultural Research, 6(6), 1525-1537.

Ochilo, W. N., Otipa, M., Oronje, M. L., Chege, F., Lingeera, E. K., Lusenaka, E., \& Okonjo, E. O. (2018). Pest management practices prescribed by frontline extension workers in the smallholder agricultural subsector of Kenya. Journal of Integrated Pest Management, 9(1), 15, 1-9. https://doi.org/10.1093/jipm/pmy009

Okolle, N. J., Afari-Sefa, V., Jean-Claude, B., Tata, P. I., \& Ngome, F. A. (2017). An evaluation of smallholder farmers' knowledge, perceptions, choices and gender perspectives in vegetable pests and diseases control practices in the humid tropics of Cameroon. International Journal of Pest Management, 62(3), 165-174. https://doi.org/10.1080/09670874.2016.1184772

Okonya, J. S., \& Kroschel, J. (2016). Farmers' knowledge and perceptions of potato pests and their management in Uganda. Journal of Agriculture \& Rural Development in the Tropics \& Subtropics, 117(1), 87-97. 
Padel, S. (2001). Conversion to organic farming: A typical example of the diffusion of an innovation. Sociologic Ruralize, 41, 40-61. https://doi.org/10.1111/1467-9523.00169

Parsa, S., Morse, S., Bonifacio, A., Chancellor, T. C., Condori, B., Crespo-Pérez, V., ... Dangles, O. (2014). Obstacles to integrated pest management adoption in developing countries. Proceedings of the National Academy of Sciences, 111(10), 3889-3894. https://doi.org/10.1073/pnas.1312693111

Piñero, J. C., \& Keay, J. (2018). Farming practices, knowledge, and use of integrated pest management by commercial fruit and vegetable growers in Missouri. Journal of Integrated Pest Management, 9(1), 1-11. https://doi.org/10.1093/jipm/pmy011

Rijal, J. P., Rajendra, R., Ghimire, R., Krishna, D. P., Sudan, G., \& Poudel, S.(2018). Farmers' knowledge on pesticide safety and pest management practices: A Case Study of Vegetable Growers in Chitwan, Nepal. Agriculture, 8(1), 16. https://doi.org/10.3390/agriculture8010016

Rumbidzai, D. K., Paramu, L. M., \& Augustine, G. (2017). Farmer knowledge of climate change impacts and adaptation strategies in the management of vegetable insect pests in Zimbabwe. Journal of Agricultural Science, 9(12), 1916-9760. https://doi.org/10.5539/jas.v9n12p194

Segura, H. R., Barrera, J. F., Morales, H., \& Nazar, A. (2004). Farmers' perceptions, knowledge, and management of coffee pests and diseases and their natural enemies in Chiapas, Mexico. Journal of Economic Entomology, 97(5), 1491-1499. https://doi.org/10.1603/ 0022-0493-97.5.1491

Shuichi, M., Yusaku, K., Mika, K., Yuichi, M., Yoshinao, A., Sengdeaune, S., ... Shinya, O. (2011). Indigenous utilization of termite mounds and their sustainability in a rice growing village of the central plain of Laos. Journal of Ethnobiology \& Ethnomedicine, 7, 24. https://doi.org/10.1186/1746-4269-7-24

Sileshi, G. W., Elias, K., Patrick, M., \& Philip, O. N. (2008). Farmers' perceptions of tree mortality, pests and pest management practices in agroforestry in Malawi, Mozambique and Zambia. Agroforest System, 72, 87-101. https://doi.org/10.1007/s10457-007-9082-5

Tebkew, D., \& Ojiewo, C. O. (2016). Current status of wilt/root rot diseases in major chickpea growing areas of Ethiopia. Archives of Phytopathology \& Plant Protection, 49, 9-10.

Tebkew, D., \& Ojiewo, C. O. (2016). Incidence and within field dispersion pattern of pod borer. Helicoverpa armigera (Lepidoptera: Noctuidae) in chickpea in Ethiopia. Archives of Phytopathology \& Plant Protection, 50, 17-18. https://doi.org/10.1080/03235408.2017.1401758

Tefera, T. (2004). Farmers' perceptions of sorghum stem-borer and farm management practices in eastern Ethiopia. International Journal of Pest Management, 50, 35-40. https://doi.org/10.1080/096708703100016 26356

Thanavendan, G., \& Jeyarani, S. (2010). Effect of different temperature regimes on the biology of Bracon brevicornis Wesmael (Braconidae: Hymenoptera) on different host larvae. Journal of Biopesticides, 3(2), 441-444.

Tiwari, S., Mann, R. S., Rogers, M. E., \& Stelinski, L. L. (2011). Insecticide resistance in field populations of Asian citrus psyllid in Florida. Pest Management Science, 67, 1258-1268. https://doi.org/10.1002/ps.2181

Van der Maesen, L. J. G. (1987). Origin, history and taxonomy of chickpea. In M. C. Saxena, \& K. B. Singh (Eds.), The Chickpea (pp. 11-34). CAB International, Wallingford, UK.

Wasihun, Y. (2016). Biological control of chickpea pod borer, Helicoverpa armigera Hubner (Lepidoptera: Noctuidae): A global concern. World Scientific News, 45(2), 92-11.

World Bank, Food and Agriculture Organization, International Fund for Agricultural Development. (2009). Gender in agriculture: Sourcebook. World Bank Publications, Washington, DC.

Wright, D., Hammond, N., Thomas, G., MacLeod, B., \& Abbott, L. K. (2018). The provision of pest and disease information using Information Communication Tools (ICT); an Australian example. Crop Protection, 103, 20-29. https://doi.org/10.1016/j.cropro.2017.08.023

Yimer, S. M., Ahmed, S., Fininsa, Ch., Tadesse, N., Hamwieh, A., \& Cook, D. R. (2018). Distribution and factors influencing chickpea wilt and root rot epidemics in Ethiopia. Crop Protection, 106, 150-155. https://doi.org/10.1016/j.cropro.2017.12.027 
Zahid, M. A., Islam, M. M., Reza, M. H., Prodhan, M. H. Z., \& Begum, M. R. (2008). Determination of economic injury levels of Helicoverpa armigera (Hubner) in chickpea. Bangladesh Journal of Agricultural Research, 33(4), 555-563.

Zhang, W., Edward, K., Felix, B., Prapti, B., Gerrit, G., \& Werf, W. (2018). Farmers' perceptions of crop pest severity in Nigeria are associated with landscape, agronomic and socio-economic factors. Agriculture, Ecosystems \& Environments, 259, 159-167. https://doi.org/10.1016/j.agee.2018.03.004

\section{Copyrights}

Copyright for this article is retained by the author(s), with first publication rights granted to the journal.

This is an open-access article distributed under the terms and conditions of the Creative Commons Attribution license (http://creativecommons.org/licenses/by/4.0/). 